University of Nebraska - Lincoln

DigitalCommons@University of Nebraska - Lincoln

Nebraska Cooperative Fish \& Wildlife Research Nebraska Cooperative Fish \& Wildlife Research Unit -- Staff Publications

2004

\title{
Anglers' Probabilities of Catching Record-Size Fish
}

Gene R. Wilde

Texas Tech University, gene.wilde@ttu.edu

Kevin L. Pope

University of Nebraska-Lincoln, kpope2@unl.edu

Follow this and additional works at: https://digitalcommons.unl.edu/ncfwrustaff

Part of the Other Environmental Sciences Commons

Wilde, Gene R. and Pope, Kevin L., "Anglers' Probabilities of Catching Record-Size Fish" (2004). Nebraska Cooperative Fish \& Wildlife Research Unit -- Staff Publications. 86.

https://digitalcommons.unl.edu/ncfwrustaff/86

This Article is brought to you for free and open access by the Nebraska Cooperative Fish \& Wildlife Research Unit at DigitalCommons@University of Nebraska - Lincoln. It has been accepted for inclusion in Nebraska Cooperative Fish \& Wildlife Research Unit -- Staff Publications by an authorized administrator of DigitalCommons@University of Nebraska - Lincoln. 


\title{
Anglers' Probabilities of Catching Record-Size Fish
}

\author{
Gene R. Wilde* And Kevin L. Pope \\ Wildlife and Fisheries Management Institute, Mail Stop 2125, \\ Texas Tech University, Lubbock, Texas 79409, USA
}

\begin{abstract}
Most state fishery management agencies publish lists of the largest (e.g., 10, 25, and 50) specimens of each species captured by anglers. We fitted normal distributions for smallmouth bass Micropterus dolomieu and striped bass Morone saxatilis and a mixture of two normal distributions of largemouth bass Micropterus salmoides to the length of time that individual fish had been present on lists of the largest 50 specimens of each species caught by Texas anglers using rod and reel. In any given year, there is only a probability $(p)$ of 0.102 that a largemouth bass large enough to make the recordweight list will be captured. There is a smaller probability that a record-weight smallmouth bass $(p=0.032)$ or striped bass $(p=0.021)$ will be captured in a given year. We suggest that record-weight lists with long turnover times (implying low probabilities that anglers will catch record-weight fish) may discourage interest and participation in angling, and we propose modifications to current record lists.
\end{abstract}

Most U.S. state fishery management agencies publish lists of the largest (e.g., 10, 25, and 50) specimens of each species captured by anglers, which are often maintained as part of angler recognition programs. Although the primary purpose of angler recognition programs is to promote and stimulate interest in recreational angling, Quinn (1987) suggested several possible uses for the data collected as part of these programs, such as identifying the characteristics of lakes that produce trophy fish and evaluating management actions. However, with few exceptions (Modde and Scalet 1985; Wilde and Pope 2004, this issue), these data have received little use. In this paper we present an analysis of the time that three species of fish remain on a state record-weight list that is maintained as part of an angler recognition program. We assess anglers' chances of catching recordweight fishes and suggest modifications of recordweight lists published in many states, and we comment on the utility of statistical models for assessing changes in the frequency of capture of record-weight fish.

\footnotetext{
* Corresponding author: gene.wilde@ttu.edu
}

Received May 28, 2003; accepted October 9, 2003

\section{Methods}

The weights of the 50 largest largemouth bass Micropterus salmoides, smallmouth bass $M$. dolomieu, and striped bass Morone saxatilis captured by recreational anglers and entered into Texas angler recognition programs were obtained from the Texas Parks and Wildlife Department website (http://www. tpwd.state.tx.us/fish/infish/records/records.phtml) on 9 May 2003. All fish (except one largemouth bass) were captured from public water bodies, including impoundments and rivers, by anglers using rod and reel. Because of ties, there were 52 fish on the smallmouth bass state record-weight list and 51 on the striped bass state record-weight list.

We calculated the number of days as of 9 May 2003 that each fish had been on one of the recordweight lists. We fitted normal and gamma distributions to each set of observations using maximum likelihood and assessed the goodness of fit using the likelihood-ratio statistic, which has a chisquare distribution. In the case of largemouth bass, there was significant lack of fit that could be resolved only by modeling the data as a mixture of two normal or gamma distributions. We fitted normal and gamma distributions to the data and estimated the mixture proportions using maximum likelihood, and assessed the goodness of fit using the likelihood-ratio statistic. Overall, normal distributions provided better fits to the observations than did gamma distributions; therefore, we present only results from fitting normal distributions to the data. Analyses were performed using version 2.3 of Mix (Ichthus Data Systems, Hamilton, Ontario). We used the Excel (Microsoft Corp., Seattle, Washington) spreadsheet function NORMDIST to calculate the probability (over time) of catching a largemouth bass, smallmouth bass, and striped bass large enough to earn placement on its respective record-weight list.

\section{Results}

Fish on record-weight lists ranged in weight from 6.89 to $8.25 \mathrm{~kg}$ for largemouth bass, 2.78 to $3.60 \mathrm{~kg}$ for smallmouth bass, and 14.25 to 24.06 $\mathrm{kg}$ for striped bass. The length of time that fish had been on the current record-weight lists ranged 


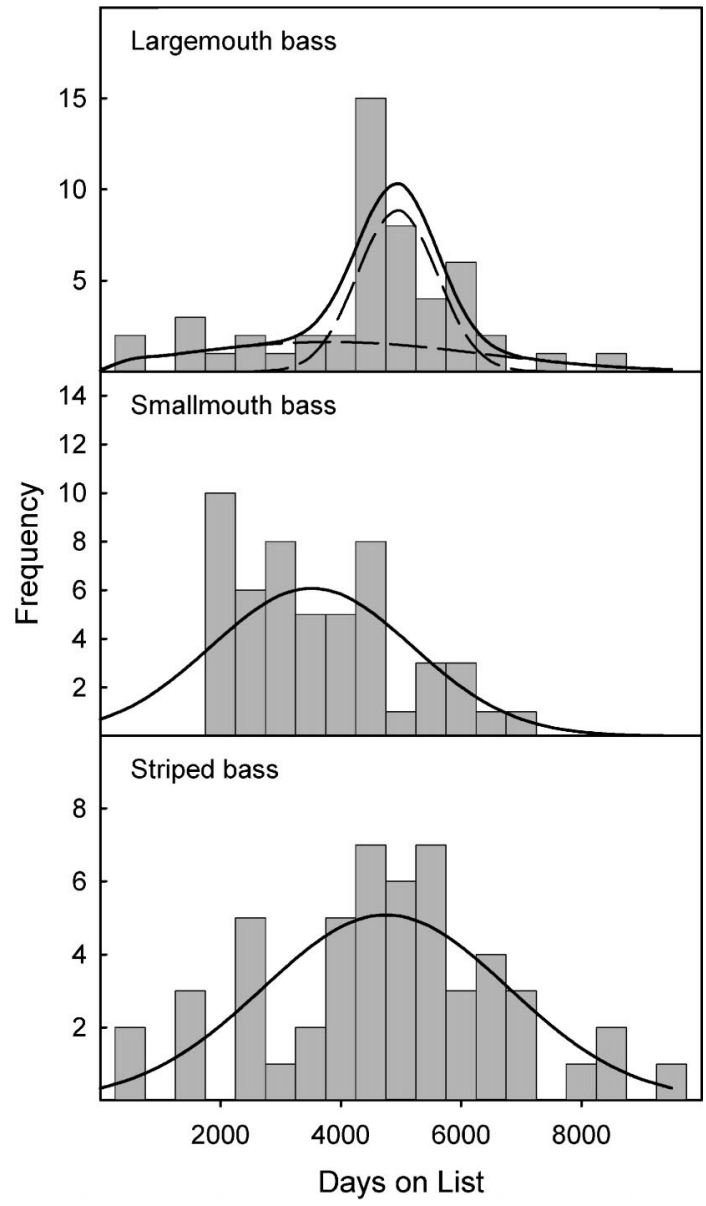

FIGURE 1.-Histograms and normal distributions fitted to observations of the length of time that largemouth bass, smallmouth bass, and striped bass remained on state record-weight lists of the 50 largest specimens captured from Texas freshwaters. For largemouth bass, a mixture of two normal distributions (dashed lines) was fitted to the data; the solid line is the combined probabilities of these two normal distributions.

from 413 to $8,126 \mathrm{~d}$ for largemouth bass $($ mean $=$ $4,232 \mathrm{~d}$ [11.6 years]), 1,535 to $7,463 \mathrm{~d}$ for smallmouth bass (mean $=3,402 \mathrm{~d}[9.3$ years] $)$, and 31 to $8,936 \mathrm{~d}$ (mean $=4,510 \mathrm{~d}$ [12.4 years]) for striped bass. Length of time on the record-weight list was bimodal for largemouth bass and, consequently, was modeled as a mixture of two normal distributions $\left(\chi^{2}=17.5094, \mathrm{df}=11, P=0.0937\right.$; Figure 1). The length of time that smallmouth bass $\left(\chi^{2}=6.4772, \mathrm{df}=8, P=0.5939\right)$ and striped bass $\left(\chi^{2}=21.7179\right.$, df $\left.=16 ; P=0.1525\right)$ were on record-weight lists was unimodal and well fit by normal distributions (Figure 1).

Cumulative probability distribution functions

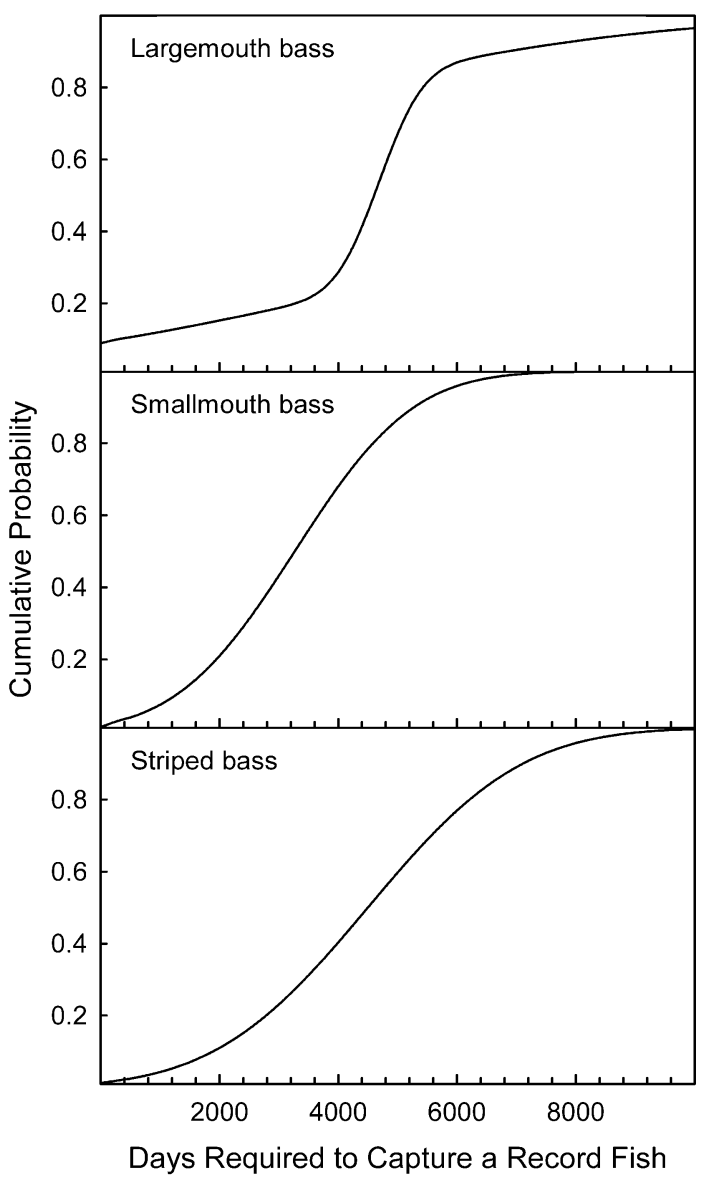

FIGURE 2.-Cumulative probability distributions for the normal distributions fitted in Figure 1, illustrating the probability that a largemouth bass, smallmouth bass, or striped bass captured in the next $n$ days will be large enough to make state record-weight lists of the 50 largest specimens of their species.

(Figure 2) for the three species show the probability of replacing a largemouth bass, smallmouth bass, or striped bass on their respective state record-weight lists over time. The probability that a largemouth bass large enough to make the recordweight list will be captured by an angler in the next year is 0.102 ; the probability that one will be captured in the next 5 years is 0.147 ; and the probability that one will be captured in the next 10 years is 0.228 . For smallmouth bass, the probabilities that a fish large enough to make the recordweight list will be captured in the next 1,5 , and 10 years are $0.032,0.179$, and 0.597 , respectively. For striped bass, the probabilities that a fish large enough to make the record-weight list will be cap- 
tured in the next 1,5 , and 10 years are 0.021 , 0.094 , and 0.338 , respectively.

We can use these probabilities to estimate an angler's chance, on any given trip, of catching a fish large enough to make one of the current recordweight lists. In 2001, anglers fished 12,315,000 d for black basses (Micropterus spp.), and 6,471,000 d for temperate basses (Morone spp. and their hybrids) in Texas (U.S. Fish and Wildlife Service 2002). If we assume that all of the black bass effort is directed toward largemouth bass or smallmouth bass, and that all of the temperate bass effort is directed toward striped bass, we estimate the chances that an angler (on any given trip) will catch a fish large enough to make the current Texas record-weight list as follows: largemouth bass, 1:120,735,294 angler-days; smallmouth bass, 1:384,843,750 angler-days; and striped bass, 1:308,142,857 angler-days. This estimate is likely to be reasonably close for largemouth bass because most black bass effort is directed toward that species. If we assume that only $10 \%$ of the black bass effort or $10 \%$ of the temperate bass effort is directed towards smallmouth bass or striped bass, respectively, the chances of catching an individual of either species large enough to make a record-weight list is still small (smallmouth bass, $1: 38,484,375$ angler-days; and striped bass, 1:30,814,286 angler-days).

\section{Discussion}

The probabilities of catching record-weight fish presented here are specific to Texas; however, our familiarity with similar lists from several other states leads us to believe that anglers have comparably small chances of catching record-weight fish elsewhere. Large, record-weight fish are at the extreme range of variation inherent in their species; therefore, additions to established lists should occur infrequently. In the absence of any major change in program promotion or management that might affect angler participation, we would expect the turnover on record-weight lists, such as those examined herein, to be inversely proportional to the length of time that the lists have been maintained. Because Texas record-weight fish lists have been continuously maintained since 1974 , the lists we assessed are fairly mature and turnover is low. The mean length of time that fish have been on these lists ranged from 9.3 to 12.4 years, and at least one specimen of each of the three species examined has been on the top-50 record-weight lists for over 20 years. A number of states have angler recognition programs and record-weight lists that predate those in Texas (Quinn 1987), so the turnover rates for lists in those states might be expected to be lower than those estimated here.

It is unlikely that anglers would perform any formal analysis of information obtained from state record-weight or other lists, such as that presented here. However, it is reasonable to assume that anglers will make rough estimates of the average time that fish have been on record-weight lists and how long it has been since a new entry was made into, for example, the top 5 or 10 positions on those lists, and use these estimates to assess their chances of catching record-weight fish. We are unfamiliar with any assessment of the impact that record-weight lists have on angler behavior or satisfaction (e.g., Hudgins and Davies 1984). In the absence of such assessments, we believe the information and messages communicated by these lists should be carefully considered when they are constructed and distributed. Quinn (1987) presented a cautionary example. After an angler recognition program was initiated in North Dakota, anglers began to view as "insignificant" any fish too small to be entered into that program. It is likely that record-weight lists similarly have a potential to affect angler behaviors and expectations.

Our results suggest that the length of time that fish have been on a record-weight list can be modeled reasonably well with a normal distribution (or a mixture of such distributions); given the small size of the lists modeled $(N=50-52)$, the lack of fit evident in Figure 1 is not unexpected. This approach provides a means for assessing and monitoring changes in the frequency with which the largest, rarest fish (i.e., trophy fish) are captured. Because such captures are unusual events, their rarity makes it difficult to discern and interpret patterns or changes in their occurrences that may result from changes in environmental conditions or management actions. For example, the bimodal distribution of length of times that the 50 largest largemouth bass have been on the Texas state-record weight list suggests that anglers sampled two populations of fish, perhaps reflecting changes in fishery management or angling techniques in the last decade. This bimodal distribution is not the result of fairly recent catches of largemouth bass from new reservoirs or to changes in existing impoundments; most (34 of 50) largemouth bass on the record-weight list, as well as four of the six most recently captured fish, were taken from a single reservoir (Lake Fork). Further, because this reservoir is among those that have consistently received substantial introductions of Florida largemouth bass $M$. salmoides floridanus, changes in 
genetic structure are unlikely to explain these catches. We speculate that the smaller, more recent mode represents a strong year-class produced during conditions favorable for largemouth bass reproduction and survival, which resulted in the production of a large number of rapidly growing largemouth bass. Crawford et al. (2002) similarly suggested that a greater-than-average incidence of trophy fish was related to the production of a strong year-class that continued growing well throughout their life. We believe that long-term (>50 years) databases of trophy catches (e.g., top 250) would facilitate assessments of trophy fish management activities and the interpretation of factors (abiotic and biotic) that affect the production of extremely large fish.

\section{Management Implications}

Fishery managers have known for some time that angler expectations, and hence satisfaction (Driver and Knopf 1976; Holland and Ditton 1992), can be influenced by providing anglers with catch rate or other fishery information (Hudgins and Davies 1984; Spencer and Spangler 1992). Record-weight lists constitute one source of fishery information that is readily available to anglers. We believe that some current record-weight lists, although perhaps useful for bragging rights or promoting specific fisheries with records of producing large fish, have little utility as a means for stimulating interest in recreational angling. Rather, these lists might instead discourage participation in the fishery by creating the impression that fishing quality is declining because large fish were regularly caught only in the past "when fishing was better" or that catching a fish large enough to be placed on a list is an unobtainable goal. We suggest that instead of utilizing long-term lists for stimulating angler interest, managers might more effectively stimulate interest in fishing and recruit anglers by publishing revolving lists of the largest fish caught in the past year or past 5 years. Such lists would show frequent changes in membership and would offer evidence that large fish are regularly captured.

Because there will always be interest in the maximum weight attained by various species in each state, lists of all-time record-weight fish should be maintained. However, the length and distribution of these lists should be considered in light of their potential to affect angler behavior and satisfaction. Lists intended for general distribution might best be limited to presenting only the top five or 10 largest individuals of each species.

\section{Acknowledgments}

We thank Chris J. Chizinski and Bart W. Durham for comments on the manuscript. Funding for this study was provided by Texas Tech University. This is contribution T-9-988 of the College of Agricultural Sciences and Natural Resources, Texas Tech University, Lubbock.

\section{References}

Crawford, S., W. F. Porak, D. J. Renfro, and R. L. Cailteux. 2002. Characteristics of trophy bass populations in Florida. Pages 567-581 in D. P. Philipp and M. S. Ridgway, editors. Black bass: ecology, conservation, and management. American Fisheries Society, Symposium 31, Bethesda, Maryland.

Driver, B. L., and R. C. Knopf. 1976. Temporary escape: one product of sport fishery management. Fisheries 1(2):21-29.

Holland, S. M., and R. B. Ditton. 1992. Fishing trip satisfaction: a typology of anglers. North American Journal of Fisheries Management 12:28-33.

Hudgins, M. D., and W. D. Davies. 1984. Probability angling: a recreational fishery management strategy. North American Journal of Fisheries Management 4:431-439.

Modde, T., and C. G. Scalet. 1985. Latitudinal growth effects on predator-prey interactions between largemouth bass and bluegills in ponds. North American Journal of Fisheries Management 5:227232.

Quinn, S. P. 1987. The status and usefulness of angler recognition programs in the United States. Fisheries 12(2):10-16.

Spencer, P. D., and G. R. Spangler. 1992. Effect that providing information has on angler expectations and satisfactions. North American Journal of Fisheries Management 12:379-385.

U.S. Fish and Wildlife Service. 2002. 2001 National survey of fishing, hunting, and wildlife-associated recreation. U.S. Fish and Wildlife Service, Washington, D.C.

Wilde, G. R., and K. L. Pope. 2004. Relationship between lake-record weights of fishes and reservoir area and growing season. North American Journal of Fisheries Management 24:1025-1030. 